\title{
Vision 2020 Umurenge Programme Transforming Lives of Communities in Rwanda: Case of Huye Sector of Huye District
}

\author{
Dr. Isaboke Peter Kennedy Nyataya ${ }^{1 *}$, Ong'esa Lorna Nyaboke ${ }^{2}$, Dr.Moses Nyandusi \\ Matundura $^{3}$ \\ ${ }^{I}$ Senior Lecturer and Director of Academic Affairs and Quality Assurance, University of Tourism, Technology \\ and Business Studies-Rwanda, \\ ${ }^{2}$ Hospitality Management Instructor, Akilah Institute of Women-Rwanda \\ ${ }^{3}$ Lecturer, University of Tourism, Technology and Business Studies-Rwanda
}

*Corresponding Author: Dr. Isaboke Peter Kennedy Nyataya, ${ }^{1}$ Senior Lecturer and Director of Academic Affairs and Quality Assurance, University of Tourism, Technology and Business StudiesRwanda

\begin{abstract}
The present research focused on the contribution made through VUP services directed towards the enhancement of socio-economic conditions of communities in Huye Sector of Huye District in the Southern Province of Rwanda. The study mainly at examining the extent to which the Vision 2020 Umurenge Programme (VUP) has influenced the socio-economic development of communities in Huye Sector. Besides, assessing the participation of the selected respondents and the effects of VUP Public works in the selected sector. Descriptive case study research design was adopted for the study. For data collection, the researcher made use of questionnaire method, interview as well as focus group discussion method to collect primary data. A sample of forty( 40) respondents was selected from the four hundred and five(405) beneficiaries of the VUP in Huye Sector of Huye District. The Slovin's Formula was used to select representative sample size of the study. The collected data for the study was then analysed and interpreted accordingly and presented in the form of tables, charts and graphs. The findings of the prsent study may benefit policy planners in the local government on education and gender, besides, social development agencies in general, operating in the selected sector and its environs. The data gathered through the study might also used while designing for various development programmes such as those relating to poverty alleviation, education, employment, credit, public and community health as well as nutritional programme. The study covered the period 2012-2016. It was revealed that the beneficiaries of VUP held good views on the programme and the programme has enhanced the socio economic lives of the communities in the Huye Sector. The recommendations derived from the findings were addressed to the Government of Rwanda, especially Huye District administrators and Academics. The researchers recommend that the programme should strive to improve its efficiency in its payment and public work implementation systems; ensuring timely and predictable payment to its beneficiaries is critical for the VUP to be able to fulfill its social protection objectives. The local government should strengthen its monitoring system for the programme. Budget allocation for the programme in Huye Sector should also be reviewed with a view to ensuring that the VUP intervention areas benefit the targeted communities so as to uplift them from the wide spreading poverty in the area. Besides, the sector should train the would-be beneficiaries the programme in entrepreneurship skills to prepare and facilitate them to quickly establish enterprises using the cash support to be received through the VUP in the area.
\end{abstract}

Keywords: Vision 2020 Umurenge Programme, Transforming, Socio-Economic Lives, Communities

\section{INTRODUCTION}

The identification and adoption of appropriate and applicable approaches to development that not only includes economic growth but also goes beyond it, putting people at the center of development is the need of the hour in the modern society. It is against this backdrop that the United Nations initiated and introduced Eight Millennium Development Goals (MDGs).

The global mobilisation behind the Millennium Development Goals has produced the most successful anti-poverty movement in history. The landmark commitment entered by world leaders in the year 2000 to spearhead efforts directed towards the freedom of our fellow men, women and children from 
the abject and dehumanising conditions of extreme poverty was translated into an inspiring framework of eight goals and, then, into wide ranging practical steps that have enabled people across the world to improve their lives and their future prospects.

The MDGs, to a large extent, have helped to lift more than one billion people out of extreme poverty, to made inroads against hunger, enabled more girls and women to attend school than ever before and to protect our planet. They have generated new and innovative partnerships, galvanised public opinion and demonstrated the immense value of setting ambitious goals. By putting people and their immediate needs at the forefront, the MDGs have reshaped decision making in both the developed and developing countries as well.

Extreme poverty has declined significantly over the last two decades. In 1990, nearly half of the population in the developing world lived on less than $\$ 1.25$ a day; that proportion dropped to 14 per cent in 2015. Globally, the number of people living in extreme poverty has declined by more than half, falling from 1.9 billion in 1990 to 836 million in 2015. Most progress has occurred since 2000.The number of people in the working middle class living on more than $\$ 4$ a day has almost tripled between 1991 and 2015.The proportion of undernourished people in the developing regions has fallen by almost half since 1990, from 23.3 per cent in 1990-1992 to 12.9 per cent in 20142016(MDGs Report, 2015).

Different scholars and researchers around the globe have used different terms to depict the development state of developing countries including under development countries and most recently, mal-development. The later has been borrowed from the medical field and is used to describe a rather dismal condition of deficiency in functioning such as: brain malfunctioning or malnourished child. Thus, to describe development of sub-Sahara African countries as mal-development is comparing it with malnourished child. There many malnourished children on the African continent and yet a hunger amount of development aid continuous to flow(Calderon, (2010). The countries of sub-Sahara African have been consigned to the bottom of the globes rich list. In 2008 for instance $47 \%$ of the population of sub-Sahara African lived on \$1.25 a day or less United Nation (2012) but efforts have been made by African countries thus Home-Grown Initiatives to achieve Millennium Development Goals as well as wellbeing of the people.

Efforts have been made by the Government of Rwanda and its development partners to achieve the Millennium Development Goals. Following extensive consultations across the country, the Rwandan Government elaborated its Vision 2020, which aims at building a modern nation with a knowledgebased and entrepreneurial economy. Together with the Poverty Reduction Strategy Paper (PRSP), this document has served as the platform for sector policy-setting in each ministry since 2003.

The Targeting and Household Surveys conducted in 2009 in ninety(90) Vision Umurenge(Sector) Programme(VUP) show that extreme income poverty across all the VUP sectors had fallen from $39.0 \%$ in 2006/7 (EICV) to 35.1\% in 2009 (VUP). The decrease was highest in the first cohort of VUP sectors (from $32.7 \%$ to $23.9 \%$, a fall of $8.8 \%$ ), $26.9 \%$ of household output is female- headed households are much poorer than male-Headed households, the VUP surveys provide a baseline to Improvements in human poverty dimensions such as on education, health, food security and Nutrition, and water and sanitation as well as gender balance (UNICEF, 2009).

Rwanda is predominantly rural with $83 \%$ of the $10.5 \%$ of Rwandans living in rural areas. It is expected that VUP will contribute towards the socio-economic uplift of over the $70 \%$ of the population which is still engaged in substance farming. The World Bank (2014) noted that the Vision 2020 was an aspiration for Rwanda to become a modern, strong and united nation, proud of its fundamental values, politically stable and without discrimination amongst its citizens. Hence, the Vision set out the aim for Rwanda to become a middle-income country by the year 2020 .

The Economic Development and Poverty Reduction Strategy (EDPRS II), as major tool for pursuing Rwanda's growth and development agenda points out its guiding principles which include innovation, strong focus on emerging priorities, inclusiveness and engagement, which should be district led development and ensure sustainability. Community development and local economic development are crucial ingredients in achieving both Rwanda's vision 2020 and the goals of the EDPRS which have mushroomed from the Millennium Development Goals. EDPRS is a part of the great vision 
2020, a strategy for improving the quality of life for all Rwandans towards the vision goal of becoming middle income country, carried out in five year phase.

EDPRS is a Programme of the Government of Rwanda, launched in 2000, to be implemented in two phases. The First Phase of EDPRS Project was implemented during the period 2008-2012, which according to the MINECOFIN (2013 helped in uplifting hundred thousand( 100000) Rwandans out of extreme poverty .The Second Phase of the Project (2013-2018) aims at reducing poverty among twenty percent of the population, elimination of extreme poverty and inclusive growth.

Vision 2020 Umurenge Programme (VUP), which is the subject of the present study, was born out of the necessity to implement the aforementioned comprehensive approach directed towards the enhancement of the socioeconomic lives of Rwandans at the grassroots level( all sectors) throughout the country. VUP itself is being implemented at various levels to ensure sustainable reduction of extreme poverty in the local communities in particular and social economic development of Rwanda in general. The Vision2020 Umurenge Programme (VUP) is the flagship of the Vision 2020 decentralised to ensure the implementation of community development Programmes particularly those directed towards poverty alleviation at the grassroots level.

\subsection{Statement of the Problem}

Rwanda is viewed as one of the countries in the world with the lowest incomes per capita, at about 1500 dollars per year, basing on purchasing power parity. In the recent past, the country has made great efforts to improve its economy and make a quick recovery from the past wars including genocide. Low incomes and social exclusion have remained key problems in Rwanda's rural areas despite the concerted efforts to reverse the aforementioned by both the Government of Rwanda and its development partners. Hence, this calls for an approach to development that includes not only economic growth but also goes beyond it and that puts people at the center of development.

The Vision 2020 Umurenge Programme (VUP), originated from the MDGs and it is an initiative of the Government of Rwanda in collaboration with developed countries partners and NGOs, The main objectives of VUP are sustained graduation from poverty will be achieved through ensuring stronger linkages to complimenting public programmes. It also aims to eradicating extreme poverty by 2020 , by creating off-farm employment opportunities and accelerating the process of monetization and formalization of the economy, in its three components( public works, direct support and credit packages)

Berglund, (2012) asserted in her study that VUP Public Works, in Gicumbi and Gasabo districts enabled subsistence peasants to make enough money to plan for bigger projects and realise wishes they have had for a long time. In contrast, Hartwig, (2013) asserted that many households do not participate in various VUP sectors due to distance to public works, hard work and low wages. However, challenges remain, a good number of Rwandans is still poor and to many others living conditions still need to be improved especially in areas of education and employment.

Huye Sector is one of poorest sectors of Huye District. The present study examined the extent to which Vision 2020 Umurenge Programme has influenced the socio- economic development of the communities in the district. The poor in Huye Sector have been facing several problems emanating from their low incomes and related problems, which include poor health, poor nutrition, illiteracy and low esteem that hinder its socio-economic development.

\subsection{Objectives of the Study}

The general objective of the present study was examining the extent to which Vision 2020 Umurenge Programme has influenced the socio-economic development of the communities in Huye Sector of Huye District. The specific objectives of the study were assessing the contribution of Vision 2020 Umurenge Programme towards the betterment of the socio-economic lives of the communities in Huye Sector of Huye District and analysing the effects of the VUP public works on the respondents.

\subsection{Significance of the Study}

The data gathered for the present study will serve as database for future researchers and other interested parties, which then facilitate them to make informed decisions, saving time, finances and other resources while implementing the VUP in the selected study area and its surrounding environs. 
The findings of the study in one way or the other are likely to benefit the social policy planners in the local government and other development partners on education and gender issues, apart from the social development agencies in the area

The obtained data through the study might help the communities within the Huye Sector and even beyond to know what they need in order to improve their present social and economic conditions. The study will facilitate the implementers of the VUP enhance their efficiency in delivering their respective services to the communities in the selected sector and even beyond the adoption of the appropriate strategies identified by the study. The Academics in various educational institutions in Huye Sector in particular and other sectors of the Huye District and the neighbouring districts in general will be some of the key beneficiaries of the present study for the information gathered therein will be of great help in their academic endeavours, as referral material.

\subsection{Limitation of the Study}

The findings of the present study will mainly benefit the implementers of the VUP in the sector covered under the present study. However, the effects of spillovers may not be ruled out and hence, the surrounding sectors in the Huye District and other neighbouring districts are likely to be, too, beneficiaries of the study

\subsection{Scope of the Study}

The main focus of the present study was to understand the contribution the Vision 2020 Umurenge Programme (VUP) has made so far to the socio- economic lives of the communities of Huye District. The study was conducted in Huye Sector of Huye District, which was selected due to the fact it is considered as one of the well-performing districts as regards to the performance contracts (Imihigo) signed between the districts and the National Government of Rwanda. Besides, Huye Sector is the one of three sectors of Huye City which, to a large extent, has somewhat better developed infrastructure. Hence, this helped the present researchers to examine in details the influence of Vision 2020 Umurenge Programme on the socio-economic lives of the communities in the sector in particular which also can be used a mirror in understanding of the VUP's public works on the selected respondents in particular and the communities in the area in general. The study covered the period between 2012-2016, for this is the period in which the implementation of the VUP was considered to have matured for it was found that its implementation in the selected area commenced in 2010.

\section{LITERATURE REVIEW}

Whereas economic growth is the quantitative increase in the amount of goods and services in any given country, economic development is both quantitative and qualitative increase in these as pointed out by Todaro and Smith (2006).It is a fact that economic growth is not the only factor to help improve the quality of life but other factors such as happiness, social needs and the environment do play a significant toward the achievement of the aforementioned.

The Government of Rwanda through the Ministry of Local Government (MINALOC) has initiated and formulated different development strategies based on the principle of improving Rwandan society through Home Grown Initiatives such as Girinkamunyarwanda, VUP and formation of SACCOs, to mention a few.

\subsection{Social Economic Development Indicators}

\subsubsection{Population}

The size and characteristics of the population is the baseline of development programmes. Such programmes are planned, organised and implemented per the qualitative (Education, development level of social structure, to name a few) and quantitative (size, sex, distribution etc.) properties of a population. The success of development schemes is directly proportional to correct interpretation of population studies and analysis as noted by Reed (2003).

\subsubsection{Education}

There is a strong relation between education level and sustainable development. The developing economy and social life needs sufficient number of educated and qualified labor force. In Rwanda, the lack of qualified labor force is always a problem. The low ratio of school enrolment from primary to 
higher education, the gender inequality problem in school enrolment, lack of educational facilities and personnel are the main problems existing for long time, as Reed noted

\subsubsection{Health}

The level of health services is directly proportional to the level of social and economic development of a region. The increase in the number of health personnel means development, as the tendency of such personnel in choosing a work place is usually directed towards the development of settlement centers. Infant mortality rates are related to development of health services, educational, culture as well as others socio- economic factor. Thus, the assessment of these parameters will help to conclude the development level of health services of a region.

\subsection{Vision 2020 Umurenge Programme}

Rwanda's Vision 2020 is a vision statement for the country's development. It presents the key priorities and pillars to serve as guiding tool for the future of the nation .it support clear Rwandan identity, whilst showing ambition and imagination in overcoming poverty and division. The Government of Rwanda (GoR) to gather with its partners, donors, civil society organizations and the private sector are all committed to make significant headways towards the objectives contained in the national vision.

During the Akagera IV Government Retreat of February 2007, it was observed by the leadership of the country that between 2000/01 and 2005/06 the poverty incidence (250frw per adult-a-day) had declined only from $60.4 \%$ to $56.9 \%$ while extreme poverty incidence (175frw per adult -a-day) had dropped from $41.3 \%$ to the $36.9 \%$ with the average income of the poor increasing from 146frw to $150 \mathrm{frw}$.at this rate of progress, it was noted that the country would only achieve the vision 2020 poverty reduction targets 2030. To remedy the situation, the vision 2020 Umurenge Programme was put in place accelerates the rate of poverty eradication, rural growth, and social protection by targeting the very vulnerable with the right mix of interventions. This way, it was envisaged that the efficiency in poverty reduction would be increased.

In 2008 Vision 2020 Umurenge Programme (VUP) started to be implemented in thirty (30) poorest sectors (imirenge), one sector for each of the 30 districts of Rwanda. The objective was to cover all the 416 imirenge in the country after the successful achievements of this start up pilot phase. By 2011, the Programme was covering ninety (90) poorest sectors, three sectors per district for all the thirty districts in the country. the VUP builds on past experiences which show that "isolated "interventions by sector, ministries, donors or NGOs are not sufficient to lift people out of extreme poverty in a costeffective and sustainable fashion.

The other extreme "integrated" development has also show its limits in many circumstances. One of the main limitations of both isolated and integrated approach has been failure to address two of the most important insights of economics: - "resources are scarce"- "people respond to incentives" because resources are scarce compared to people's needs, choices must have made. To incorporate these insights, the VUP balances central guidelines for social economic transformation with local participatory mechanisms. This ensuring adequate local incentive for sustainable progress.

\subsection{Public Works}

Public Works aim to create off-farm employment infrastructure, through paid activities such as terracing, water harvesting, irrigation, roads construction, building of classrooms, health facilities, village settlements, among others. The VUP revives public works but requires that they are planned and that they use community-based participatory approaches, for example Ubudehe to build community assets and create an off-farm employment infrastructure (MINECOFIN,2011).These community assets could be agriculture or livestock infrastructure or dedicated to promoting off-farm manufacturing or service activities. In Rwanda, public works can take place on either public or private land (e.g. terracing). However, the assets must benefit the whole community. Indeed, when such benefits are clear, the community will have the incentive to conduct the maintenance of these community assets, thereby ensuring their sustainability. In 2008, 18.304 households participated in VUP public works in 28 sectors. The number increased significantly to 61.335 households in 2009/2010 9 which is around $21 \%$ of total households in the operational sectors) of which $49 \%$ were 
female headed. $77 \%$ of eligible households participated in 2009/10, which is more than double the target of 35\% of eligible households participating during the year ( RLDSF,2012).

Amis and Kumar, (2000) investigated the relationship between urban economic growth, the provision of urban infrastructure and poverty reduction in Visakhapatnam, one of the largest port and industrial towns in India. In the study, the authors identify many dimensions of poverty, including inadequate income, lack of assets ('no shelter, no property, and no gold'), lack of support (especially for widows, deserted women and the handicapped), illness and debt. The results of participation in public work indicate that the city's growth was constrained by inadequate investment in infrastructure, especially for water and electricity.

\subsection{VUP Credit Packages}

VUP innovates with cooperative, small and medium size enterprise development and, credit packages to tackle extreme poverty as well as to foster entrepreneurship and off-farm employment opportunities; these packages are designed to make the best possible use of scarce public resources, involve the private Financial Sector (especially microfinance institutions with local presence in pilot imirenge), and provide people with incentives and organizational capacity to improve their own productive and trading capacities. Credit packages go beyond natural resources to cover human resources (i.e. skills), entrepreneurship and off-farm employment. A credit package is a formal contract that describes the use of the credit in pre-specified activities. This contract is agreed upon with the community, endorsed by the community, and approved by the VUP Management Team. It allows the bearer to benefit from the VUP Insurance Scheme (VUPIS), which will facilitate the credit approval by local microfinance institutions (MINECOFIN,2007)

\subsection{VUP's Direct Support}

Includes direct supports to improve access to social service or to provide for landless households with no members qualifying for public works or credit packages; such unconditional supports seek to expand health and education coverage as well as to encourage the development of appropriate skills, handicraft, or social service activities and it is prioritized and 100\% funded (MINECOFIN, 2007). It will allow redirecting social protection to the neediest people who are landless and unable to work, thereby rationalizing and improving the effectiveness of social protection programs, along the social protection strategy. During January-June 2009, mini budget year, transfers were made to 6.850 households. This increased to 9.692 households during 2009/10, approximately 3.5 of all households in the sectors. Extremely poor households in Rwanda with no labor capacity contain adults who are old, disabled, chronically sick or still in school, or have no adults at all (child-headed households) MINECOFIN (2007). Vision 2020UmurengeProgram (VUP) provides work on community infrastructure projects (terracing, irrigation, building of classrooms, construction of access roads, etc.). Households eligible for VUP public works are extremely poor (in the bottom two Ubudehe categories) who are "landless" (less than 0.25 ha) but who have at least one adult (18 years+) able to do manual labor. In addition to benefiting individual households, the program benefits the community at large in the form of increased assets.

\subsection{VUP's Contribution in Socio-Economic Development}

The programme sought to increase the "efficiency in poverty reduction" by ensuring that economic growth rapidly translates into poverty reduction. This efficiency is measured by the elasticity of poverty reduction with respect to real per capita consumption growth. Improving such efficiency required improvement in the "efficiency of service delivery", an important component of the Decentralization Implementation Program (DIP). It follows that the DIP should support the VUP (EDPRS, 2007). VUP has employed several people through public infrastructures, while directly supported those who were unable to work and others came up with savings in SACCOs (Stephen , 2012). The VUP built on past experiences which showed that isolated interventions by sectors, ministries, donors or NGOs are not sufficient to lift people out of extreme poverty in a cost-effective and sustainable fashion. Even integrated approach did not fit the target as they both failed to address two of the most important insights of economics namely scarcity of resources and the fact that people need incentives (RLDSF,2010). To incorporate these insights, the VUP balances central guidelines for socio-economic transformation (i.e. economic growth, job creation and extreme poverty eradication) 
with local participatory mechanisms. This ensures the best possible use of scarce resources while, respond at the same time, ensuring adequate local incentives for sustainable progress

\subsection{Main Challenges to the VUP}

Although the VUP requires complex mechanisms to ensure efficiency in both coordination across sector, ministries and implementation at local levels, the aim can be achieved by focusing on key objectives and guiding principles. The VUP aims to eradicate extreme poverty by 2020 . This aim will eventually be achieved through acceleration in poverty reduction along by Releasing the productive capacities of people and offering solutions adapted to their needs; Improving community livelihood assets (e.g. eco-systems rehabilitation) and ensuring their sustainable usage; Increasing the targeting of social protection to the most vulnerable. However, the VUP Programme has main challenges, for instance, where the delivery of benefits is done through bank accounts and proximity to financial institutions is still a challenge to some beneficiaries.Besides, there are no feasible alternatives in the poor rural communities. Alternatives being examined include, telephone banking, agent banking, mobile banking but these are some years away, Graduation definition, Establishing of a monitoring and evaluation framework which works effectively, in particular building of a data base of reliable, timely information has proved challenging because of capacity issues, infrastructure and communications as a core mover of social protection interventions, VUP is challenged to spearhead coordination of safety nets which are implemented in different institutions, as observed by Justine Gatsinzi (2011).

Narayan et al. (1999) carried out an analysis of a number of research documents for the World Bank on 47 countries and conducted interviews basing on these documents in what we called participatory poverty Assessment (PPA). Several Questions were asked for each researcher ought to answer, namely; if poverty is undesirable why is it persistent? If poor people are not lazy why has poverty remained a social problem? The main concept in this research across the globe were the subvariables of poverty namely; deprivation, hunger, powerlessness, violation of dignity, resilience, social isolation, resource fullness, corruption, rudeness of services providers, gender inequality.The research which was exploratory in nature concluded that economic dislocation and sweeping changes have produced conflict at the household, community, regional, and national levels leading to breakdown of social cohesion in group and disrupting connection a cross groups. The study also found that poor people lack material assets and depend on the social insurance provided by the strength of their social ties, a breakdown of community solidarity and norms of reciprocity with neighbors and kin affects poor people more than other groups. But good governance can help the people to lift out extreme poverty through policy integration, transparency, community development and infrastructures development.

Michell and Alison (2003) carried out a study on the factors of employment. In their analysis, they came to conclusion that for welfare to function for the aim of its beneficiaries there have to be comprehensive sub- programmes for capacity building to make their own social networks (social capital). In the USA, the OPRE (2015) carried out a research, examining the local implementation of the federal temporary assistance for Needy families (TANF) programs and policies, the intersection of TANF with safety net programs and other relevant issues. The main areas focused on were: employment and the labor market; education and training, other and cross-cutting research within these areas.

Since the creation of the Temporary Assistance for Needy Families Programme in 1996, there have been needy individuals who may be eligible for TANF cash assistance but are neither receiving TANF nor working OPRE(2015) Several studies carried out before explored the circumstances of disconnected families. This related to a research urban institute, using a qualitative approach to address important knowledge gaps related to these disconnected families, work, benefit receipt, economic coping strategies, material hardship, and over all well- being. The human resources development as a factor in economic development was also researched. Lucas (1988) consider three models based on evidence; the physical capital accumulation model, the technological change model and, the human capital accumulation. The ratter model is achieved through schooling and learning by doing.

According to Thugge et al (2013), Vision 2030 in Kenya focuses on improving health, housing and urbanization, protection of the environment and, gender, youth and protection of vulnerable group. 
According to the researchers the mechanisms to achieve these goals include the country's rethinking its development paradigm with a view to generate domestic resources. This will be led by strengthening, the capital markets and strengthening of banking sector and mobilization of savings. In Bangladesh, a research on microfinance found that it did not require lot of money to get rid of poverty but good will and political will. The donors provided financial assistance to the poor but let them control their own lives. The same investigation found that while visionary leadership cannot simply be franchised, the systems governing the successful microfinance industry in Bangladesh can to an extent be replicated. These may vary according to the size of organization, but by and large, the successful organisation delegated significant decision- making authority away from head offices, monitored individual staff performance, and liked staff incentives to program targets. Client feedback and program monitoring are also fundamental.

Several researches have been carried out on welfare and social- economic development, but, from the perspective of the economy of the area concerned with limited view of the socio- cultural perspective. Narayan et al (1999) sponsored by the World Bank, carried a research around the world (surveying 47 countries). In this research, the investigation explored the causes and effect of poverty but the Solutions advocated a dependency approach where the poor have to be helped directly by the rich to get out of their misery.

Researchers conducted on VUP include the one carried out by Rose (2015), Ansom and Rostagno (2012). They all advocated for a more inclusive concept of growth, which would then appear to be crucial not only for successful poverty reduction but also with a view to promoting long-term stability and peace in Rwanda. Further, they pointed out that growth model founded indigenous strengths and capacity building among small scale farmers was crucial to the country

It has also been noted in scholarly domains that socio-economic development can be attained through a combination of structural, cultural changes. The beneficiaries of socio development programmes have to be empowered to change and their attitude in order to be fully transformed where Culture (human behavior) affects economic outcomes as observed by Hezel (2009) and Fischer (2014).

\section{RESEARCH METHOdOLOGY AND RESEARCH DESIGN}

The study employed descriptive research design.

\subsection{Target population}

The target population included the beneficiaries of VUP and Huye district, Huye sector Officials. The beneficiaries were in the three lower categories under Ubudehe. Getting these people out of poverty is the most concern of the government. In total there were 405 household's beneficiaries in Huye Sector ( Huye District Report, 2014).

\subsection{Representative Sample Size}

The total population of the present study was 405.Therefore,in order to determine the representative sample size, is Solvang's Formula was employed. Hence, the representative sample size of the study comprised 36 beneficiaries of the VUP in the Huye Sector, besides, two district officials and two sector officials, making the total respondents to be forty (40).

\subsection{Sources of Data and Method of Data Collection}

The study made use of both primary and secondary sources of data. The primary data were obtained through interviews conducted by the researchers and questionnaire administered to the respondents selected for the study. Secondary data was obtained from the documents available and reviewed, which included the sector registers, district records and reports such as the bank accounts owned and operated by the local saving and credit cooperatives.

\section{Findings OF THE STUDY}

The study found that the beneficiaries of VUP, generally, held good opinions about the programme. It was observed that the communities in the area have benefitted and hence, improved their socioeconomic status as result of the proper implementation of in the Huye Sector. The respondents were noted to be in general agreement with the view that their life had been improved as a result of VUP, not only on the improved access to school by their children but also on the enhancement of the needed 
health facilities. Most of the respondents were found to have atleast attended elementary schools. They also attested to the fact they had been mostly involved in constructing schools for their communities. The local leaders pointed out that they regularly mobilise the communities in the area on the importance of education. The study showed that the majority of the respondents indicated that they were planning on how to start small business through loans provided and public work allowances. Only 5\% of the respondents were found to have improved access to drinking and irrigation water, however, it was noticed that the majority of them was engaged in businesses. The VUP was seen an integrated local development programme designed with a view to accelerating the process of poverty reduction, rural growth and also bring about improved wellbeing of the people at the grassroots. In Huye Sector, true to its aims, the VUP was noted to have positively influenced the socio-economic development of the sector. The findings, too, showed that a good number of beneficiaries of VUP participated involved in efforts directed towards improved market infrastructures. $12.5 \%$ of them were observed to have been involved in the improvement of clustered village settlements. Besides, the majority was agreement that they participated in improving land productivity in the area. It was noted that money received through public works helped the beneficiaries of VUP to meet their basic needs such as in paying for their health insurance in addition to paying school fees for their school-going children. A great number of the respondents said that public work allowances they received helped them to buy clothes for themselves and their children. The majority claimed that they have initiated income generating activities such as animal rearing including goat, chicken and pig rearing besides, the cultivation of fruits and green vegetables.

During focus group discussion held with the respondents, the majority pointed out that they were happy due to the fact that they were able to carry out small business as result of money received from public works which they were engaged in. The coordinator of VUP in Huye District, said that "Life conditions of people in the area had been improved, they, now, have access to electricity, improved water supply and in addition, their children have access to schools mainly through the support received through the VUP. The incomes earned by the beneficiaries have enabled them to have access to health insurances". This shows that the VUP Public work has had positive effects on social economic development of the communities in Huye Sector.

The study found that $85 \%$ of the respondents had received loans. It was worth noting, here, that that a substantial number of the respondents had requested and received credits during the VUP implementation either individually or collectively. The local leaders covered in the study commented that credit packages of VUP were important and profitable to the beneficiaries as they were charged an interest of only $2 \%$, which was lower that than that is charged by either banks or SACCOs, for instance, Banque Populaire, charges its borrowers an interest of $18 \%$ whereas SACCOs, generally, stand at an interest of $22 \%$. Five percent (5\%) of the respondents reported that they received direct support from VUP. To the present researchers, the aforementioned was due to the fact the majority of the respondents were observed to be participating in public works while direct support focused on people that were unable to work due to old age or suffer of life chronic and threatening conditions. The VUP coordinator confirmed that elders and others who could not participate in public works received direct supports in terms of money ( $\mathrm{Rwf} 9000 /$ month).Hence, is worth mentioning that the direct support was seen to a booster in the socio-economic development of the sector for it was found to have lowered the degree of dependency in the area.

\section{CONCLUSION}

The researchers conclude that the VUP has contributed a great deal towards betterment of the wellbeing of communities in Huye Sector. The people are now able to meet their basic needs such food, clothes, access to the health insurance, access to schools and are, too, to carry out small business in the area. The respondents' participation in the VUP Public works has brought positive changes to their life in particular and that of their communities in general, for they are able to pay school fees for their school-going children, besides, increasing their capacity to buy clothes for themselves and for their relatives. The present researchers, rightly, conclude that overall, the VUP support programme has enabled the communities in the Huye Sector to make significant strides in their social-economic spheres and hence, if the aforesaid, can be emulated and be adopted by the neighbouring sectors and beyond, communities in Rwanda, in general, would have improved their socioeconomic lives, to a large scale. 


\section{RECOMMENDATIONS}

The present researchers emphasise that the VUP should strive to improve its efficiency in terms of its payment and public work implementation systems. Ensuring timely and predictable payments to their respective beneficiaries' payment which is critical to the VUP in its efforts of being able to fulfill its social protection objectives. Besides, the local government should strengthen its monitoring system of the programme. Series of trainings conducted for the VUP staff with a view to enhancing their capacity in monitoring and reporting skills.

The researchers are of the view that the budget allocated for the Programme in Huye Sector should also be reviewed to ensure that the in the area are freed from the chains of poverty under which they find themselves. Besides, the sector should train its would-be beneficiaries in entrepreneurship skills, well in advance, on how to plan and implement business enterprises. The VUP managers in collaboration with the government and policy makers should recognise the fact that once wages are received in time, the beneficiaries will be able to meet their basic needs and hence, help their respective families, apart from facilitating their school-going children. The local government should seek partnership with private sector, civil society and other interested parties with whom they can work together with a view to uplifting the social and economic lives of the communities in the selected and in expanding the number of activities presently being undertaken the VUP in the area.

\section{REFRENCES}

[1] AmartyK.Sen,(1984), collective choice and social welfare, ch.3, " collective rationality".p.33 and ch3*," social welfare functions."

[2] Amis, P., \& Kumar, S. (2000). Urban economic growth, infrastructure and poverty in India: lessons from Visakhapatnam. Environment and Urbanization, 12(1), 185-196.Arturo Escobar (2012), Encountering Development the making and unmaking of the Third World, Princeton University Press, New Jersey, United Kingdom.

[3] Asselin, L. (2009). Vision 2020 Umurenge Program targeting and poverty surveys, social impact M\&E expert Vision 2020 Umurenge Program M\&E technical Advisor

[4] Babbie,Earl (2007) Thepractice of Social Research Eleven Edition, BelmotCA; Wordsworth.

[5] Bryman, A, \& Bell, E. (2011) Business research methods, Third Edition Oxford, Oxford University Press

[6] Byerlee, D. de Janvry, A. and E. Sadoulet. (2009). "Agriculture for Development Toward a New Paradigm", Annual Review of Resource Economics, Vol. 1: 15-35, October 2009

[7] Calderon and Serven, L (2010). Infrastructure and Economic Development in Sub-Saharan Africa. Journal of African Economies , 19(Suppl 1), 13-i87Economic Planning, Available from

[8] Fan, S., Hazell, P., \&Thorat, S. K. (2000). Impact of public expenditure on poverty in rural India. Economic and Political Weekly, 3581-3588

[9] Fernando Cardoso (1979), Dependency and development in Latin America, University of Calfornia Press.

[10] General Economics Division Planning Commission Government of people's Republic of Bangladesh (2005). Bangladesh Unlocking the potential retrieved from:

[11] Halarambos, Michael \&Holborn, Martin (2000) Sociology. London; Imprint

[12] Hartwig, R. (2013). Public works as means to push for poverty reduction? Short-term welfare effects of Rwanda's Vision 2020 Umurenge Program: UNU-WIDER conference on Inclusive Growth in Africa.

[13] International Monetary Fund (IMF) country report No. 05/National strategy for accelerated poverty reduction 2005 retrieved

[14] International Monetary Fund IMF (2013) Country report No. 13/360 2013 January 29,2001January 29, 2001. Washington, D.C

[15] Jahan, S and McCleery, R. (2005). Making infrastructure work for the poor. Synthesis Report for Four Country Studies: Bangladesh, Senegal, Thailand and Zambia. United Nations Development Program.

[16] Jerome, A., \& Ariyo, A. (2004, October). Infrastructure reform and poverty reduction in Africa. In African development and poverty reduction: the macro-micro linkage. TIP/DPRU Forum (pp. 13-15).

[17] Justine Gatsinzi (2011) Social Protection South- South Learning Forum 2011

[18] Lake, C. (1987). Public opinion polling: A handbook for public interest and citizen advocacy groups. Island Press

[19] Livermore, Michelle \& Neustrom Alison (2003) Linking welfare client to jobs; Discretionary Use of Worker Social Capital, Journal of Sociology and social welfare, Vol XXX, Number 2 
[20] Lucas, Robert E. Jr (1988) on the mechanics of economic development. Published by Elsevier B.V OPRE Report 2015-15 portfolio of research in welfare and family Self-Sufficiency

[21] Majid Rahnema Paperback (1999), The Post - Development Reader, University of Chicago Press

[22] Martinez,E.\& Glenzer,K,.(2005). Proposed Global Research Framework For Care's Strategic Impact inquiry on women's Empowerment; Atlanta; Care Usa.

[23] Michael p. Todaro and Stephen.C Simith (2011) Economic development, pearson, New York, United State

[24] Midgely, James (1999) Social development; the development perspective in social welfare; London; Sage Publishers.

[25] Ministry of Finance and Economic Planning (2007). EDPRS Poverty Analysis of Ubudehe. Kigali

[26] Ministry of Finance and Economic planning (2013). Economic development and poverty Reduction Strategy retrieved from Ministry of Local Government (2016)

[27] Narayan, Deepa et al. (2000), can Aynone Hear US? Voice of the poor; World Bank Publication.

[28] National Institute of Statistic of Rwanda (2009). The third Integrated Household Living Conditions Survey $(E I C V)$ : Main Report. Kigali: NISR.

[29] National Institute of Statistic of Rwanda (2015) Social protection and and Vision 2020 Umurenge Programme Report

[30] Ogun, T. P. (2010, August). Infrastructure and poverty reduction: Implications for urban development in Nigeria. In Urban Forum (Vol. 21, No. 3, pp. 249-266). Springer Netherlands.

[31] Pimpare, Stephen (2013) Welfare Reform at 15 and the state of policy Analysis; social work, v58nl p53-62

[32] Reed, M. (2003). Situating indicators of social well-being in Rural Saskatchewan communities. University of Saskatchewan, Community University institute for social research. University of Saskatchewan.

[33] RoR. (2007). Economic Development and Poverty Reduction Strategy, 2008-2012: Draft (110907). Kigali

[34] Sachs, Jeffrey D. (2005) The end of poverty; economic possibilities for our Time. New York; penguin books.

[35] Todaro, Michael\& Stephen Smith (2006). Economic development. $9^{\text {th }}$ ed. Addison-Wesley series in economics,

[36] Tudor. (2012) Korea: the impossible country, Nelson, Richard R. and Howard Pack. (2007).

[37] Zaman, Hassan (2004) Reducing poverty sustaining- what worlks, what doesn't and why A Global Exchange for scaling up Success a Global Learning process and conference shanghai, May 25-

Citation: Dr. Isaboke Peter Kennedy Nyataya PhD, Ong'esa Lorna Nyaboke, Dr.Moses Nyandusi Matundura, Ph.D. "Vision 2020 Umurenge Programme Transforming Lives of Communities in Rwanda: Case of Huye Sector of Huye District" International Journal of Research in Sociology and Anthropology (IJRSA), vol 4, no. 2, 2018, pp. 6-16. doi:http://dx.doi.org/10.20431/2454-8677.0402002.

Copyright: () 2018 Authors. This is an open-access article distributed under the terms of the Creative Commons Attribution License, which permits unrestricted use, distribution, and reproduction in any medium, provided the original author and source are credited. 